\title{
Why does stock price always behave like a roller coaster? A glimpse from the perspective of disposition effect and herd behavior
}

\author{
Yifei $\mathrm{Li}^{1, \mathrm{a}}$ \\ ${ }^{1}$ Hubei Medical College, Shiyan 442000, Hubei, China \\ aliyifeiatmail@163.com
}

\begin{abstract}
Keywords: Disposition effect, Herd behavior, Regret aversion, Behavioral finance, Information economics
\end{abstract}

\begin{abstract}
This study aims at when the new information appears in the stock market under the interaction influence of disposition effect and herd behavior, how the stock price will change? Taking these two common investor's psychological phenomena into consideration, I follow the track of pervious researches mainly aims at the interaction of these two phenomena in stock market. As a result, I found the disposition effect cause lag of time of the price reaching the actual value price in the fluctuation of stock market principally. The herd behavior stimulating the market to break though the actual value price and reach a higher price. I also noticed that these two different psychological phenomena may have a same trigger which is the regret aversion. This standpoint is helpful for investors to avoid traps in the stock market and make decisions more precisely.
\end{abstract}

\section{Introduction}

It is universally acknowledged that whenever news happened in stock market the tendency in reaction to the information which means securities are rationally valued to reflect available information. However, individual decision makers do not behave in accordance with the shown messages, earlier studies have indicated that stock prices appear to drift after news announcements. For instance, Frazzini found evidence of investors' underreaction to the news under the influence of disposition effect [1]. Park and Sabourian indicate that when herding behavior exist, investors overreaction to the information [2]. From the study of Kahneman and Tversky we concluded that prospect theory is the essential point to explain the phenomenon [3].

The Value Function has been created by Kahneman and Tversky as a fundamental function of prospect theory, as it has been widely used in behavior economy, to demonstrate how individuals make decision under risk.

Shefrin and Statman indicate that the investors have the tendency to hold the losing stocks too long and to sell the wining stocks too soon which had been labeled as the disposition effect [4]. Odean states the measurement of gap between realized stocks and unrealized stocks to find the individual has disposition effect, and the same result has been found in the later literature reviews as each individual has a behavior bias in disposition effect and results in unexpected investment performance [5].

Choi illuminates the point that investors who have the disposition effect will affect price change in the market [6]. Weber and Camerer clarifies that the disposition effect will greatly reduce when shares are automatically sold as period [7]. Da Costa Jr Newton and Mineto Carlos and Da Silva Sergio show that in stock market females have less disposition effect than males [8]. Alan D. Crane and Jay C. Hartzell make the point that the disposition effect is stronger for smaller properties [9]. 
Nicholas Barberis and Wei Xiong says that the disposition effect could be analyzed by using the realized gains and losses and it reflect the investor's strategies [10]. Tom Chang and David H. Solomon and Mark M. Westerfield states that Cognitive dissonance could enabled disposition effect [11]. Cary Frydman and Antonio Rangel indicate that it is possible to debias the disposition effect by reducing the saliency with information [12]. Ravi Dhar and Ning Zhu proved that inexperienced investors are more susceptible to the disposition effect than sophisticated investors [13].

Herding behavior is often used to describe as an investment strategy to trading stocks in the same direction as demonstrated by a group of investors within a certain period. Kraus and Stoll and Klemkosky found evidence of herding behavior among mutual fund managers $[14,15]$. Nofsinger and Sias concluded that the herding behavior among retail and institutional investors was caused by positive feedback trading [16]. Ennis and Sebastian as well as Boyson showed herding tendency of trading behavior among hedge fund managers $[17,18]$. Kim and Jegadeesh pointed out the herding tendency of investment recommendations made by analysts [19].

As stated by Bikhchandani, Hirschleifer, and Welch, the direct result of such herding behavior is to create the correlation in trades among individuals and therefore systematic mistake by entire markets [20].

This thesis will discuss when new information appears, under the influence of disposition effect and herding behavior, how the stock prices will change? We will study respectively from the perspective of the disposition effect and herding behavior to analysis when new information appears, what is the tendency of stock prices. And to discuss when the disposition effect and herding behavior act together in the stock market how will the price trend presented.

\section{Model}

In stock market, when new information arrives, under the influence of disposition effect and herd behavior, how will stock prices change. All information is public information and available to all investors, no discussion is made of privileged information. Only disposition effect and herd behavior affect investor's decision making, and other factors are not discussed (such as the evaluation of future stock price fluctuation, decision-makers' personal factors, etc.).

The coordinate axis is established with t0 as the origin. The vertical axis is Price, while the horizontal axis is time. And $t 0$ is the point where new information appears. When new information is a positive news: the model of the condition of market under the influence of disposition effect and herd behavior is found as an equation: $\mathrm{P}=-\alpha \mathrm{t} 2+\beta \mathrm{t}+\mathrm{P} 0$. The t0 represent the time when new information appears in the coordinate as $\mathrm{t} 0=0$, the $\mathrm{t}$ is limit $\mathrm{t} \geqslant 0 ; \mathrm{P} 0$ is the constant and limit $\mathrm{P} 0>0$.

Given $\alpha$ is taken from set $(0, \infty), \alpha$ is the result of disposition effect and herd behavior interaction, since disposition effect and herd behavior is the psychological factor of investors, they will influence the decision maker all the time.

Given $\beta>0, \beta$ it affects the height of the vertices.

All above assumption is about the positive news, when there is a negative news, vice-versa.

\section{Result}

When new information appears, according to utility theory, the price should immediately become the actual price reflecting the new information; however, the reality is different, when new information appears at time t0, the fluctuation of the stock market shown as Figure 1.

P1 reflects the actual value of stocks under the action of new information according to the utility theory. As for $\mathrm{t} 0$ - $\mathrm{t} 1$ is the actual time required for the price to change from $\mathrm{P} 0$ to $\mathrm{P} 1$, reflecting the 
result of disposition effect and herd behavior affect the decision maker, because the price did not reach the actual value immediately, is mainly represented by the lag effect of disposition effect. For $\mathrm{t} 1$ - $\mathrm{t} 3$ reflects the price overflow of the actual price, reflecting the result of disposition effect and herd behavior affect the decision maker, since the price exceeds the actual value which is mainly manifested as the stimulation effect of herd behavior.

As can be seen from Figure 1, as $\alpha$ approaches infinity the function become narrower, the narrower the function is, the shorter the time it takes for the price to reach the actual value, and the more obvious of the stimulation effect of herd behavior is. On the contrary, as $\alpha$ approaches zero the function become wider, the wider the function is, the longer the time it takes for the price to reach the actual value, and the more distinctive of the lag effect of disposition effect is.

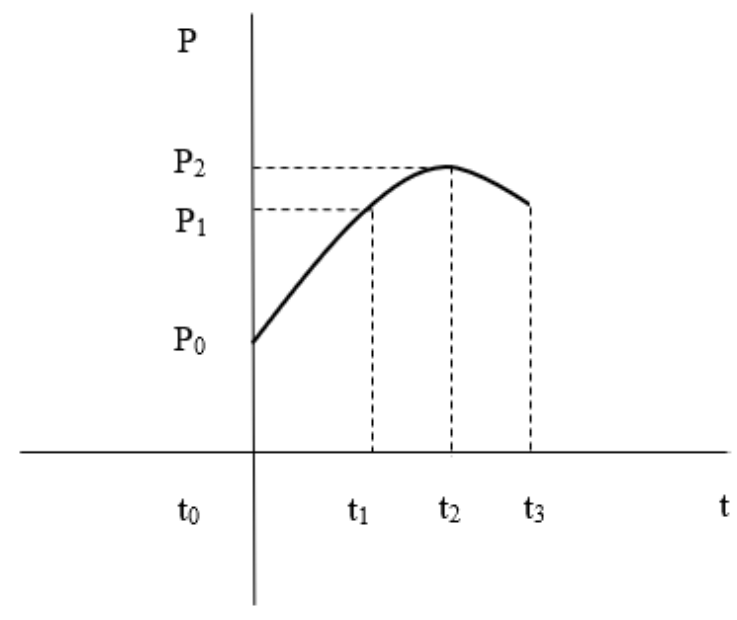

Figure 1 Prices change over time

The investors enter at $\mathrm{t} 0$, and the market price is $\mathrm{P} 0$. The decision maker is under the influence of disposition effect and herd behavior.

At time t0, there is new information reflecting the real related value of the stock, and investors receive new information at the same time. Investors may respond to new information in three ways: holding, selling and buying. The new information reflects the new real value of the stock as P1.

When the actual value $\mathrm{P} 1$ is greater than $\mathrm{P} 0$;

When more investors receive new information but do not buy stocks, the longer time the stock takes to reach the actual value, the greater the $\alpha$ is, indicating that the lag effect of disposition effect is more evident.

When more investors buy stocks timely after receiving new information, the shorter the time it takes for stocks to reach the actual value, the smaller $\alpha$ is, demonstrating the more obvious the stimulation effect of herd behavior.

The same is true when the actual value P1 is less than P0.

When the absolute value of stock value exceeds the absolute value of real value, it is mainly reflected as the stimulation effect of herd behavior.

The more obvious the herding behavior of the investors, the greater difference between absolute value of $\mathrm{P} 2$ and $\mathrm{P} 1$, and besides, $\beta$ affects the height of the vertex $\mathrm{P} 2$. When $\alpha$ is a deterministic value, the change in the slope of the connection between $\mathrm{P} 2$ and $\mathrm{P} 1$ is affected by $\beta$. And the greater the $\beta$ is, the greater the slope is. As a result, the greater the slope, the more obvious of the herd behavior.

\section{Discussion}

As investors become more sophisticated, the time of $\mathrm{t} 0$ - $\mathrm{t} 1 \mathrm{will}$ be shorter, because skilled investors will reduce the effect of disposition effect [21]. Similarly, as the market become more mature, the 
time of $\mathrm{t} 1-\mathrm{t} 3$ will be shorter too, since sophisticated decision makers will decline the herd behavior as well.

This thesis mainly states that when new information appears, under the interaction influence of disposition effect and herd behavior, how the market price changes with time, among which disposition effect and herd behavior have different characteristics, thus, when new information arrives, disposition effect mainly lags behind the time when the market price reaches it actual value. When new information comes out, herd behavior is mainly manifested as the stimulation effect, even if the market price breaks the actual value. Disposition effect and herd behavior has a similar place, both of which are decisions made by investors to avoid regret.

Much of the discussion about the herd behavior has been about whether it will occur, and little attention has been paid to why investors themselves behave it. T. Liao, C. Huang, and C. Wu found a solution to this problem [22]. Individuals mostly intent to avoid regret so they act as herd behavior unconsciously. Of course, a few investors are using the herd behavior rationally.

The discussion of the disposition effect has focused on the impact of the effect on different markets. Conversely, shall we focus on the decision makers themselves. Prospect theory provides an explanation for this problem from the perspective of avoiding regret, but experienced investors have their own unique and strict methods of avoiding the disposition effect to some extent [23].

For herd behavior and disposition effect, have one thing in common, the two effects are people's actions to avoid regret, on the market just became the projection of the discrepancy between the utility theory and the reality. As far as I'm concern, when researching how will the new information bring the changes to the market which have been dominated by herd and disposition effect, should be noticed that people tend to avoid regret, it is this tendency led to people's irrational investment.

Research on regret aversion, Daniel Kanhneman put forward action effect, consider the investor who sell the stock (action), will be more regret than who did not (inaction) [24]. In the case of uncertainty, people are more inclined to inaction, in the event of loss, the choice of inaction can relieve people's regret. This provides an explanation for the lagging effect of disposition effect. When the market changes, people always choose not to act in order to alleviate the possible regret, thus delaying the investment decision and leading to the emergence of disposition effect.

And investors are acting herd in order to avoid making the wrong decision, because at the time of the wrong decision to realize, the feeling of regret will come, but in cases where the same choices as others lead to errors, the feeling of regret will be significantly reduced, people will think others share his wrong decision, will put the blame on others, thereby reducing their sense of regret. Individuals are more likely to engage in herd behavior out of a propensity to reduce regret, which explains the herd behavior.

Because of the widespread of the disposition effect and herd behavior, when investors in the decision-making, should pay attention to avoid the above two kinds of effect of its influence, in the presence of new information to accurate judgment of the market, timely increase or stop in time, to minimize the wait time, can effectively prevent the happening of the disposition effect. To avoid the herd effect, it is important to take conscious of the herd mentality and precisely judge the actual value of the market, so as to reduce the herd behavior.

This paper studies the changing trend of market price over time under the combined impact of disposition effect and herd behavior, the subsequent research direction could be the further exploration of the interaction effects of disposition effect and herd behavior on the market reality or regret aversion of the investors. 


\section{References}

[1]. Frazzini A. The Disposition Effect and Underreaction to News[J]. Journal of Finance, 2006, 61(4):2017-2046.

[2]. Park A, Sabourian H. Herd Behavior in Efficient Financial Markets[J]. Working Papers, 2006.

[3]. Kahneman D, Tversky A. Prospect Theory: An Analysis of Decision under Risk[J]. Econometrica, 1979, 47(2):263-291.

[4]. Shefrin H, Statman M. The Disposition to Sell Winners Too Early and Ride Losers Too Long: Theory and Evidence[J]. Journal of Finance, 1985, 40(3):777-90.

[5]. Odean T. Are Investors Reluctant to Realize Their Losses? [J]. Journal of Finance, 1998, 53(5):1775-1798.

[6]. Darwin Choi. The Impact of the Disposition Effect on Liquidity and Stock Prices[J]. Ssrn Electronic Journal, 2011.

[7]. Weber M, Camerer C F. The disposition effect in securities trading: an experimental analysis[J]. Journal of Economic Behavior \& Organization, 1998, 33(2):167-184.

[8]. Newton Da Costa Jr, Carlos Mineto, Sergio Da Silva. Disposition effect and gender[J]. Applied Economics Letters, 2008, 15(6):411-416.

[9]. Crane A D, Hartzell J C. Is There a Disposition Effect in Corporate Investment Decisions? Evidence from Real Estate Investment Trusts[J]. Social Science Electronic Publishing, 2007.

[10]. Barberis N, Xiong W. What Drives the Disposition Effect? An Analysis of a Long - Standing Preference - Based Explanation[J]. Journal of Finance, 2009, 64(2):751 - 784.

[11]. Chang T Y, Solomon D H, Westerfield M M. Looking for Someone to Blame: Delegation, Cognitive Dissonance, and the Disposition Effect[J]. Journal of Finance, 2016, 71(1).

[12]. Frydman C, Rangel A. Debiasing the disposition effect by reducing the saliency of information about a stock's purchase price $\hat{\imath}^{2}[\mathrm{~J}]$. Journal of Economic Behavior \& Organization, 2014, 107(Pt B):541-552.

[13]. Dhar R, Zhu N. Up Close and Personal: An Individual Level Analysis of the Disposition Effect[J]. Yale School of Management Working Papers, 2002, 52.

[14]. Kraus A, Stoll H R. Parallel Trading by Institutional Investors[J]. Journal of Financial \& Quantitative Analysis, 1972, 7(5):2107-2138.

[15].Klemkosky R C. THE IMPACT AND EFFICIENCY OF INSTITUTIONAL NET TRADING IMBALANCES[J]. Journal of Finance, 1977, 32(1):79-86.

[16]. Nofsinger J R, Sias R W. Herding and Feedback Trading by Institutional and Individual Investors[J]. Journal of Finance, 2010, 54(6):2263-2295.

[17]. Ennis R M, Sebastian M D. A Critical Look at the Case for Hedge Funds[J]. Journal of Investing, 2003, 29(4):103-112.

[18]. Boyson N M. Implicit incentives and reputational herding by hedge fund managers[J]. Journal of Empirical Finance, 2010, 17(3):283-299.

[19]. Jegadeesh N, Kim W. Do Analysts Herd? An Analysis of Recommendations and Market Reactions[J]. Review of Financial Studies, 2010, 23(2):901-937. 
[20]. Bikhchandani S, Hirshleifer D, Welch I. Learning from the Behavior of Others: Conformity, Fads, and Informational Cascades[J]. Journal of Economic Perspectives, 1998, 12(3):151-170.

[21]. Feng L, Seasholes M S. Do Investor Sophistication and Trading Experience Eliminate Behavioral Biases in Financial Markets?[J]. Social Science Electronic Publishing, 2005, 9(3):305351.

[22]. Liao T L, Huang C J, Wu C Y. Do fund managers herd to counter investor sentiment?[J]. Journal of Business Research, 2011, 64(2):207-212.

[23]. Jr N D C, Goulart M, Cupertino C, et al. The disposition effect and investor experience[J]. Journal of Banking \& Finance, 2013, 37(5):1669-1675.

[24]. Kahneman D. The simulation heuristics[J]. Judgement Under Uncertainly Heuristics \& Biases, 1982. 